msh-mss Mathématiques et sciences humaines

193 | Printemps 2011

Varia

\title{
Formes opératoires et topologiques en linguistique
}

operators and topological forms in linguistics

Jean-Pierre Desclés

\section{CpenEdition}

Journals

Édition électronique

URL : http://journals.openedition.org/msh/11928

DOI : $10.4000 /$ msh. 11928

ISSN : 1950-6821

\section{Éditeur}

Centre d'analyse et de mathématique sociales de l'EHESS

\section{Édition imprimée}

Date de publication : 15 janvier 2011

Pagination : 99-117

ISBN : 09876936

ISSN : 0987-6936

\section{Référence électronique}

Jean-Pierre Desclés, « Formes opératoires et topologiques en linguistique », Mathématiques et sciences humaines [En ligne], 193 | Printemps 2011, mis en ligne le 01 juin 2011, consulté le 23 juillet 2020.

URL : http://journals.openedition.org/msh/11928; DOI : https://doi.org/10.4000/msh.11928

Ce document a été généré automatiquement le 23 juillet 2020.

(C) École des hautes études en sciences sociales 


\title{
Formes opératoires et topologiques en linguistique
}

Operators and topological forms in linguistics

\author{
Jean-Pierre Desclés
}

\section{RÉSUMÉS}

L'alternance géométrique-topologique / algébrique-logique qui traverse les mathématiques est mise en œuvre dans l'analyse formelle des langues naturelles. Les relations entre topologie et modalités épistémiques ont été mises en évidence par l'algèbre de Kuratowski. Les types fonctionnels de Church et la logique combinatoire de Curry, qui est une logique des opérateurs et des compositions intrinsèques d'opérateurs par des combinateurs, permettent d'analyser en profondeur la syntaxe et la sémantique des langues. La topologie étant un langage des approximations, les catégories aspecto-temporelles des langues sont des exemples d'approximations formalisées par des opérateurs topologiques. Les combinateurs se présentent comme des outils formels qui articulent explicitement des représentations topologiques avec des représentations métalinguistiques symboliques où des opérateurs aspectuels et temporels sont composés entre eux. Pour formaliser certaines situations sémantiques, il semble nécessaire de développer une formalisation mathématique de lieux abstraits quasi-topologiques.

The opposition geometry-topology / algebraic- logic pass through the field of mathematics; it is used in an analysis of language. The relations between topology and epistemic modalities are clearly manifested with the Kuratowski's algebra. Church's functional types and Curry's combinatory, which is considered as a logic of operators and intrinsic compositions of operator by combinators, are applicative formalisms useful for a deep analysis of the syntax and semantic of language. Topology being a language of approximations, the aspecto-temporal categories are examples of such approximations analysed and formalised by topological operators. The 
combinators are useful tools to articulate topological representations with formal metalinguistic representations where aspectual and temporal operators are composed together. To formalize some semantic situations of language, it is necessary to develop a mathematic formalisation of quasi-topological abstract places.

INDEX

Mots-clés : combinateurs, formes opératoires, formes topologiques, grammaires catégorielles, logique combinatoire de Curry, quasi-topologie, topologie, types fonctionnels de Church

Keywords : categorial grammars, Church's functional types, combinators, Curry's combinatory logic, operative forms, quasi-topology, topological forms, topology

\section{AUTEUR}

\section{JEAN-PIERRE DESCLÉS}

Langages, Logiques, Informatique et Cognition (LaLIC), Université Paris-Sorbonne, 28 rue Serpente 75006 Paris, jean-pierre.descles@paris-sorbonne.fr 